\title{
Prevalence of sexually transmitted infections among pregnant women with known HIV status in northern Tanzania Sia E Msuya*1,2,4, Jacqueline Uriyo ${ }^{1,4}$, Akhtar Hussain ${ }^{1}$, Elizabeth M Mbizvo1,5, Stig Jeansson ${ }^{3}$, Noel E Sam ${ }^{4}$ and Babill Stray- Pedersen $^{2}$
}

Address: ${ }^{1}$ Department of International Health, Institute of General Practice and Community Medicine, University of Oslo, Oslo, Norway, ${ }^{2}$ Department of Obstetric and Gynecology, Rikshospitalet University Hospital, University of Oslo, Oslo, Norway, ${ }^{3}$ Department of Microbiology, Ullevaal University Hospital, University of Oslo, Oslo, Norway, ${ }^{4}$ Kilimanjaro Christian Medical Centre, Moshi, Tanzania and ${ }^{5}$ Ministry of Health and Child Welfare, Harare, Zimbabwe

Email: Sia E Msuya* - siamsuya@hotmail.com; Jacqueline Uriyo - jackieuriyo@yahoo.com; Akhtar Hussain - akhtar.hussain@medisin.uio.no; Elizabeth M Mbizvo - embizvo@mweb.co.zw; Stig Jeansson - s.l.jeansson@medisin.uio.no; Noel E Sam - noelsam@kcmc.ac.tz; Babill StrayPedersen - babill.stray-pedersen@medisin.uio.no

* Corresponding author

Published: 25 February 2009

Reproductive Health 2009, 6:4 doi:10.1186/1742-4755-6-4
Received: 24 October 2008

Accepted: 25 February 2009

This article is available from: http://www.reproductive-health-journal.com/content/6/l/4

(c) 2009 Msuya et al; licensee BioMed Central Ltd.

This is an Open Access article distributed under the terms of the Creative Commons Attribution License (http://creativecommons.org/licenses/by/2.0), which permits unrestricted use, distribution, and reproduction in any medium, provided the original work is properly cited.

\section{Abstract}

Objectives: To determine the prevalence of sexually transmitted infections (STIs) and other reproductive tract infections (RTIs) among pregnant women in Moshi, Tanzania and to compare the occurrence of STIs/RTIs among human immunodeficiency virus (HIV)-infected and uninfected women.

Methods: Pregnant women in their $3^{\text {rd }}$ trimester $(\mathrm{N}=2654)$ were recruited from two primary health care clinics between June 2002 and March 2004. They were interviewed, examined and genital and blood samples were collected for diagnosis of STIs/RTIs and HIV.

Results: The prevalence of HIV, active syphilis and herpes simplex virus - type 2 (HSV-2) were $6.9 \%, 0.9 \%$ and $33.6 \%$, respectively, while $0.5 \%$ were positive for $N$ gonorrhoeae, $5.0 \%$ for $T$ vaginalis and $20.9 \%$ for bacterial vaginosis. Genital tract infections were more prevalent in HIV-seropositive than seronegative women, statistically significant for syphilis $(3.3 \%$ vs $0.7 \%), \mathrm{HSV}-2(43.2 \%$ vs $32.0 \%$ ), genital ulcers (4.4\% vs $1.4 \%$ ) and bacterial vaginosis (37.2\% vs $19.6 \%$ ). In comparison with published data, a declining trend for curable STIs/RTIs (syphilis, trichomoniasis and bacterial vaginosis) was noted.

Conclusion: Rates of STIs and RTls are still high among pregnant women in Moshi. Where resources allow, routine screening and treatment of STIs/RTIs in the antenatal care setting should be offered. Higher STIs/RTIs in HIV-seropositive women supports the expansion of HIV-counseling and testing services to all centers offering antenatal care. After identification, STIs/RTIs need to be aggressively addressed in HIV-seropositive women, both at antenatal and antiretroviral therapy care clinics. 


\section{Background}

Sexually transmitted infections (STIs) are a major public health problem, especially in developing countries $[1,2]$. They are highly prevalent among pregnant women in Africa and cause significant maternal and perinatal morbidity [2-6]. STIs and other reproductive tract infections (RTIs) have been associated with a number of adverse pregnancy outcomes including abortion, stillbirth, preterm delivery, low birth weight, postpartum sepsis, neonatal pneumonia, neonatal blindness \& congenital infection [1-4]. In addition, STIs/RTIs have been shown to facilitate transmission of HIV [7-12]. The control of STIs/RTIs, especially in pregnancy, is thus a priority, particularly in resource-poor settings where they are prevalent.

The prevalence of STIs however, has been shown to vary from one country to another and among different groups within the same country [2]. In Tanzania, the difference of STI/RTI prevalence by region, population and time-period has been observed $[3,6,13-18]$. There is thus a need to have local knowledge of the epidemiology of STIs/RTIs by periodically monitoring the prevalence of etiological agents. This information is useful in guiding clinical management, treatment protocols and to form the basis for STI surveillance. In this paper we report the prevalence of STIs/RTIs among pregnant women attending routine antenatal care in Moshi urban, Tanzania, as well as comparing the occurrence of infections among HIV-seropositive and sero-negative women. In addition, we compared the results of this study with previous published data on the prevalence of sexually transmitted infections among pregnant women in the same clinics.

To simplify the reading of the text, the acronym RTIs is used exclusively and is to be understood to include STIs as well as other non sexually transmitted diseases of the reproductive tract (i.e. bacterial vaginosis and candidiasis).

\section{Methods}

\section{Study sites and population}

The study was conducted among pregnant women attending routine antenatal care at two of the largest primary health care clinics (PHC) (Majengo and Pasua) in Moshi urban district. The district is the capital of Kilimanjaro region, situated in Northern Tanzania with the population of about 230,000 people [19]. The two clinics are the largest PHC and also represent women from the largest geographical areas (administrative wards). Attendance for antenatal care in this district is very high (>97\%) [19].

Eligibility criteria and recruitment procedures have been described in detail elsewhere [20]. Briefly, from June 2002 to March 2004, a cohort of 2654 pregnant women, in their third trimester, were invited to participate in a larger project which aimed to describe the acceptability of HIV/ RTI perinatal interventions, especially prevention of mother-to-child transmission of HIV at the PHC level as well as to determine factors associated with incident HIV and RTIs in the postpartum period. This was preceded by a pilot project in 1999 which aimed primarily at determining the prevalence of RTIs among attendees, both pregnant and non-pregnant, at primary health care clinics in the same centres [18].

After obtaining informed consent, the participants underwent counseling followed by a structured interview in Swahili to collect information on socio-demographic variables, sexual behavior, obstetric history, and on current and past RTI symptoms. After the interview, a general and gynecological examination was performed. Genital ulcers, warts and abnormal vaginal or cervical discharge were diagnosed clinically. Vaginal and cervical samples were collected for diagnosis of various reproductive tract and sexually transmitted infections. Venous blood was taken for serological analysis of HIV, syphilis, HSV-2 and Chlamydia trachomatis. Genital samples were not collected from 99 of the women (4\%) because they did not want to undergo speculum examination. The same procedures as above were followed in the pilot study in 1999 .

Pregnant women with symptoms or signs suggestive of RTIs were treated on the spot following the Tanzanian Syndromic STI Case Management Guidelines. The women were asked to return for their HIV/RTI results after one week. Women found later, on laboratory testing, to have untreated infections were treated for specific infections during the follow-up visit. HIV positive women were given a single dose of Nevirapine for prevention of mother-to-child transmission (PMTCT) of HIV at post test counseling and their infants were given Nevirapine syrup within 72 hours after delivery. All of the women were encouraged to inform their partners and to bring them for counseling and testing. Those with proven RTIs were given a contact card to give to their partners so that they could come for treatment. All the services were free of charge for both the women and their partners.

Approval for the study was obtained from the Tanzanian Ministry of Health and The Regional Committee for Medical Research Ethics; Region III (Regional komite for medisinsk forskninsetikk region III)

\section{Laboratory methods}

Active syphilis was diagnosed by positive results of both the rapid plasma regain test (RPR; Becton Dickinson, MD, USA) and a specific test, Determine Syphilis TP (Abbott Laboratories, IL, USA). HSV-2 was detected by the typespecific HSV-2 ELISA test (Focus Diagnostics, Cypress, California USA). HIV was diagnosed by a positive result 
on both the Determine HIV 1/2 (Abbott Laboratories, IL, USA) and Capillus HIV 1/2 (Trinity Biotech, Ireland). Discordant results $(<1 \%)$ were resolved by an ELISA test, Vironostika HIV Uni-form II (Organon Teknika, Boxtel, Netherlands). IgG antibodies to Chlamydia trachomatis was assessed in serum by an ELISA test (Ani Labsystems Ltd, Finland).

Trichomoniasis was diagnosed using wet preparation, candidiasis by visual inspection of Candida species on potassium hydroxide (KOH) preparations or on Gramstained vaginal swabs. Bacterial vaginosis was diagnosed on the basis of Amsel's criteria [20]. N gonorrhoeae was diagnosed by culture (modified Thayer-Martin medium) and/or positive Gram-stained of endocervical swabs for Gram-negative diplococci.

\section{Statistical analysis}

The data were entered and analyzed using SPSS statistical software, version 12.0 (SPSS, Chicago, IL, USA). Descriptive statistics were obtained through frequencies and cross tabulations. Comparison between groups was made using the $\chi^{2}$ tests and Fisher exact test when appropriate. All analyses were two-tailed and the level of significance was set at $5 \%$.

\section{Results}

The age of the 2654 participating women ranged from 1443 years (median 24 years), parity from 0-9 (median 1 ) and gestation age from 28-40 weeks (median 30 weeks). Other demographic details are described in Table 1.

The prevalence of laboratory diagnosed RTIs by HIV status is shown in Table 2. Seven percent of the women had HIV infection, $0.9 \%$ had active syphilis, $33.6 \%$ were HSV-2 positive and $17.5 \%$ had IgG antibodies for $\mathrm{C}$ trachomatis. The prevalence of $\mathrm{N}$ gonorrhoeae was low $(0.5 \%)$ while $23.9 \%$ of the women had trichomoniasis and/or bacterial vaginosis.

Except for candidiasis, the prevalence of both viral and bacterial RTIs were higher in HIV-seropositive women than in the HIV-seronegative women, significantly for syphilis $(\mathrm{p}<0.001)$, HSV-2 $(\mathrm{p}=0.03)$, gonorrhoea $(\mathrm{p}=$ $0.05)$, Chlamydia trachomatis Ab $(\mathrm{p}=0.004)$, bacterial vaginosis $(\mathrm{p}<0.001)$ and genital ulcers $(\mathrm{p}=0.002)$, Table 2.

Table 3 shows a comparison of RTI prevalence among pregnant women with published work which was carried out in 1999 at the same clinics as the current study [18]. A significant decline in curable RTIs was observed, especially for syphilis (from $3.4 \%$ to $0.9 \%$; $\mathrm{p}=0.001$ ), trichomoniasis (from $23.4 \%$ to $5.0 \%$; $<<0.001$ ) and bacterial vaginosis (from $31.4 \%$ to $20.9 \%$; $p=0.001$ ). No signifi- cant decrease was observed in the prevalence of HSV-2 infection.

\section{Discussion}

In this study viral infections (HSV-2 and HIV) are more common than the curable non-viral STIs like trichomoniasis, syphilis or gonorrhoea $[14,16,17]$. We also noted a decline of curable genital tract infections among pregnant women between 1999 and 2004. A high prevalence of HSV-2 and decreasing prevalence of curable genital tract infections like syphilis, chlamydia, gonorrhoea, trichomoniasis and bacterial vaginosis has been reported in several sub-Saharan countries among pregnant women $[15,22,23]$, among women in the general population [23], and among women in high risk groups $[16,17,23]$. The introduction of and scaling up of syndromic approach for management of STIs in most primary health clinics may partly explain the decrease $[6,23]$. The change in the genital infection spectrum however, highlights the need to strengthen STI surveillance, so as to be able to adjust syndromic management protocols according to the epidemiological situation.

Despite the declining trend, the prevalence of trichomoniasis (5\%) and bacterial vaginosis $(20.9 \%)$ are still high, considering that this was a pregnant population. Untreated, trichomoniasis (TV) has been associated with preterm birth and low birth weight (LBW), while bacterial vaginosis (BV) can cause preterm rupture of membranes, preterm birth, LBW and postpartum sepsis especially in women with a previous history of preterm delivery [2]. Prematurity and low birth weight are among the leading causes of perinatal morbidity and mortality in resourcepoor settings $[1,2,10]$. Studies have also indicated that both BV and TV may increase the risk of HIV acquisition, and BV may have an effect on mother-to-child transmission of HIV [10-12]. Efforts are thus required to treat these vaginal infections in pregnancy. An approach like presumptive treatment (mass treatment on the presumption that the disease might be present) has been associated with significant reduction in the prevalence of these infections, and in the incidence of LBW, early neonatal death and preterm delivery [4].

The active syphilis prevalence of $0.9 \%$ was similar to that reported for women in the general population $(0.2 \%)$ or among bar workers (1.1\%) in the same district $[14,17]$. However it was lower than in pregnant women in the Mwanza (7.7\%), Mbeya (4.1\%) and Kagera (14.9\%) regions in Tanzania, and among pregnant women in Uganda (3.3\%), Zimbabwe (3.4\%), Mozambique (4.7\%) and Cameroon (13\%), showing variation within and between countries in Africa [3-6,15,22,24]. Our results however might be an underestimation in the prevalence of syphilis because women with early foetal loss resulting 
Table I: Socio-demographic, behavioural and obstetric characteristics of the 2654 participating women in Moshi urban district, Tanzania

\begin{tabular}{|c|c|c|}
\hline Variable & $N=2654$ & $\%$ or range \\
\hline Age of the women (mean, range) & 24.61 & $14-43$ \\
\hline Years of residence in Moshi (mean, range) & 12.75 & $0-42$ \\
\hline \multicolumn{3}{|l|}{ Marital status } \\
\hline Married & 1624 & $61.2 \%$ \\
\hline Cohabiting & 790 & $29.8 \%$ \\
\hline Single/divorced/separated & 240 & $9.0 \%$ \\
\hline Polygamous relationship & 296 & $11.2 \%$ \\
\hline \multicolumn{3}{|l|}{ Education } \\
\hline None & 108 & $4.1 \%$ \\
\hline Primary education & 2275 & $85.6 \%$ \\
\hline Secondary and above & 271 & $10.3 \%$ \\
\hline Formally employed & 136 & $5.1 \%$ \\
\hline \multicolumn{3}{|l|}{ Income per month } \\
\hline None & 762 & $28.7 \%$ \\
\hline$<30$ USD & 1726 & $65.0 \%$ \\
\hline 30 USD and above & 166 & $6.3 \%$ \\
\hline \multicolumn{3}{|l|}{ Obstetric history } \\
\hline Parity (Mean, range) & 1.16 & $0-9$ \\
\hline Gravidity (Mean, range) & 2.35 & $1-10$ \\
\hline Prior stillbirth/previous pregnancy & $310 / 1686$ & $18.4 \%$ \\
\hline History of infant death/previous pregnancy & $14 \mid / 1686$ & $8.4 \%$ \\
\hline Age at first pregnancy (mean, range) & 19.77 & $1 \mathrm{I}-34$ \\
\hline \multicolumn{3}{|l|}{ Sexual behavior characteristics } \\
\hline Age at fist debut (mean, range) & 18.30 & $9-31$ \\
\hline Report casual partners in past 12 months & 117 & $4.4 \%$ \\
\hline Lifetime sexual partners (mean, range) & 1.61 & $1-7$ \\
\hline Condom use at sexual debut & 240 & $9.0 \%$ \\
\hline Report of ever use of condoms & 670 & $25.2 \%$ \\
\hline Treatment for STI symptoms in past 12 months & 685 & $25.8 \%$ \\
\hline
\end{tabular}

from syphilis would not be represented, since we recruited women in the third trimester [3]. Lumbiganon et al (2002) showed that even with a low background prevalence of $0.9 \%$, women with syphilis had significantly more adverse pregnancy outcomes e.g. LBW and perinatal death [25]. Syphilis screening and treatment in pregnancy is thus cost-effective even at prevalences $<1 \%$ and supports the WHO recommendation to perform serological screening on all pregnant women at first visit [1]. With resources being mobilized for expansion of prevention of 
Table 2: Prevalence of laboratory confirmed reproductive tract/sexually transmitted infections by HIV status among pregnant women in Moshi, Tanzania

\begin{tabular}{|c|c|c|c|c|}
\hline & $\mathbf{N}$ & $\%$ & HIV-positive & HIV-negative \\
\hline \multicolumn{5}{|l|}{ Serology } \\
\hline HIV-I & $184 / 2654$ & $6.9 \%$ & & \\
\hline Active syphilis & $23 / 2654$ & $0.9 \%$ & $3.3 \%$ & $0.7 \% * * *$ \\
\hline HSV-2 & $427 / 127 \mid$ & $33.6 \%$ & $43.2 \%$ & $32.0 \% * *$ \\
\hline Chlamydia trachomatis & $183 / 1048$ & $17.5 \%$ & $30.0 \%$ & $16.6 \% * *$ \\
\hline \multicolumn{5}{|c|}{ Cervical \& vaginal STIs/RTIs } \\
\hline Neisseria gonorrhoea & $13 / 2555$ & $0.5 \%$ & $1.6 \%$ & $0.4 \% *$ \\
\hline Trichomonas vaginalis & $129 / 2555$ & $5.0 \%$ & $7.1 \%$ & $4.9 \%$ \\
\hline Bacterial vaginosis & $533 / 2555$ & $20.9 \%$ & $37.2 \%$ & $19.6 \% * * *$ \\
\hline Candida albicans & $292 / 2555$ & $11.4 \%$ & $14.2 \%$ & $11.2 \%$ \\
\hline Any vaginal infection $\pi$ & $754 / 2555$ & $29.5 \%$ & $46.4 \%$ & $28.2 \% * * *$ \\
\hline \multicolumn{5}{|l|}{ Clinical STIs } \\
\hline Genital ulcer & $4 I / 2555$ & $1.6 \%$ & $4.4 \%$ & $1.4 \% *$ \\
\hline Genital warts & $1 \mathrm{I} / 2555$ & $0.4 \%$ & $1.1 \%$ & $0.4 \%$ \\
\hline Any curable STI \# & $162 / 2558$ & $6.3 \%$ & $11.5 \%$ & $5.9 \% * *$ \\
\hline Any curable STI/RTI † & $633 / 2558$ & $24.7 \%$ & $43.2 \%$ & $23.3 \% * * *$ \\
\hline
\end{tabular}

I Trichomoniasis, bacterial vaginosis or candidiasis.

\# Syphilis, gonorrhoea, trichomoniasis.

† Syphilis, gonorrhoea, trichomoniasis, bacterial vaginosis.

$*_{p} \leq 0.05, * * \mathrm{p}<0.01, * * * \mathrm{p}<0.001$

mother-to-child transmission of HIV programs in most sub-Saharan African countries, this opportunity should be used to expand syphilis screening and treatment at the same time.

The higher prevalence of STIs and bacterial vaginosis among HIV-seropositive women than seronegative women has also been reported among pregnant women in Zimbabwe, Cameroon, Thailand and USA $[5,8,24]$. HIV-infected people have higher rates of genital infection probably because of shared behavioral risk factors that facilitate transmission of both infections [7], or increased susceptibility to some RTIs like gonorrhoea and GUD, especially with advanced immune suppression [26]. RTIs in HIV-infected women has been associated with more severe adverse reproductive health outcomes than in uninfected women, including pelvic inflammatory disease, high grade cervical intraepithelial lesions, postpartum endometrititis, preterm birth and neonatal death $[2,24,25]$. Also, the presence of bacterial vaginosis, candidiasis, trichomoniasis, gonorrhoeae, chlamydia and HSV2 in HIV-infected women, increases HIV genital shedding, thus an increased concentration of HIV in genital secretions $[9,10,28,29]$. Increased infectiousness increases the risk of both vertical and sexual HIV transmission. In fact, studies have recently shown that bacterial vaginosis, chorioamnionitis, genital ulcers and HSV-2 are associated with increased rates of mother-to-child HIV transmission $[8,10,30,31]$. Efforts to expand HIV-counseling and testing services to all centers offering antenatal care is vital in order to identify HIV-infected women. Apart from offering antiretroviral therapy (ART) to reduce perinatal HIV 
Table 3: Trend by age groups of laboratory confirmed STIs/RTIs among pregnant women in Moshi urban, 1999-2004

\begin{tabular}{|c|c|c|c|}
\hline STI/RTI & I5-24 years & $25-49$ years & Total \\
\hline \multicolumn{4}{|c|}{ Number of participants } \\
\hline 1999 & 78 & 98 & 176 \\
\hline $2002-04$ & 1467 & 1187 & 2654 \\
\hline \multicolumn{4}{|l|}{ HSV-2 } \\
\hline 1999 & $26.9 \%$ & $41.8 \%$ & $35.2 \%$ \\
\hline $2002-04$ & $28.9 \%$ & $38.8 \%$ & $33.5 \% \leftrightarrow$ \\
\hline \multicolumn{4}{|l|}{ Syphilis } \\
\hline 1999 & $1.3 \%$ & $5.1 \%$ & $3.4 \%$ \\
\hline $2002-04$ & $0.5 \%$ & $1.3 \%$ & $0.9 \% \downarrow$ \\
\hline \multicolumn{4}{|c|}{ Gonorrhoea } \\
\hline 1999 & $1.3 \%$ & $0.0 \%$ & $0.6 \%$ \\
\hline $2002-04$ & $0.6 \%$ & $0.4 \%$ & $0.5 \% \leftrightarrow$ \\
\hline \multicolumn{4}{|c|}{ Trichomoniasis } \\
\hline 1999 & $26.0 \%$ & $21.4 \%$ & $23.4 \%$ \\
\hline $2002-04$ & $5.4 \%$ & $4.6 \%$ & $5.0 \% \downarrow$ \\
\hline \multicolumn{4}{|c|}{ Bacterial vaginosis } \\
\hline 1999 & $26.0 \%$ & $35.7 \%$ & $31.4 \%$ \\
\hline $2002-04$ & $23.4 \%$ & $17.7 \%$ & $20.9 \% \downarrow$ \\
\hline \multicolumn{4}{|c|}{ Any curable STI/RTI $\dagger$} \\
\hline 1999 & $41.6 \%$ & $51.0 \%$ & $46.9 \%$ \\
\hline $2002-04$ & $27.2 \%$ & $21.7 \%$ & $24.7 \% \downarrow$ \\
\hline
\end{tabular}

† Syphilis, gonorrhoea, trichomoniasis, bacterial vaginosis.

$\downarrow$ significant decrease in prevalence; $\leftrightarrow$ no change in prevalence.

transmission, the women should also be offered screening for genital tract infections. Treatment of genital infection significantly lowers genital HIV concentrations $[9,10,28,29]$, thus treatment of maternal genital infections in HIV-infected women during pregnancy may substantially reduce negative reproductive effects on the women themselves, may reduce sexual HIV transmission and play a part in reducing mother-to-child transmission. Efforts to address RTIs in HIV-infected women should not be limited to pregnancy but should also be extended to ART care clinics.

There may be possible limitations in the study regarding some of the laboratory tests used to diagnose RTIs. Culture and microscopy were used to diagnose gonorrhoeae and trichomoniasis in this study. Nucleic acid amplification technology using polymerase chain reaction (PCR) has been shown to have a higher sensitivity and specificity than culture and microscopy for identification of both gonorrhoea and trichomoniasis [32,33]. The traditional tests used might have thus missed a substantial proportion of these infections. Further, we used an IgG antibody test to diagnose Chlamydia trachomatis. This test can only show the proportion of women who had been exposed to the Chlamydia infection in the past. It cannot differentiate between women with active and with past infections. Therefore it may be used only for epidemiological studies and not for diagnosing women for treatment.

Despite the possible limitations, the study has demonstrated that STIs and other reproductive tract infections are still prevalent among pregnant women in the area. Routine screening and treatment during antenatal care is recommended. HIV-infected women should receive adequate screening for genital tract infections during pregnancy. Future research and public health preventive efforts should target not only the classical bacterial RTIs but also HSV-2 as it was the most prevalent STI. Lastly, studies using more sensitive assays (PCR) for screening STIs during pregnancy are required, in order to give a more precise picture of STI occurrence.

\section{Competing interests}

The authors declare that they have no competing interests.

\section{Authors' contributions}

SEM designed the study, recruitment of participants, collected and entered data, analyzed data and drafted the 
manuscript. JU participated in data collection, laboratory testing and data analysis, revising the drafted manuscript. AH conception, design, analysis and reviewed the drafted manuscript. EM designed the study, participated in analysis and interpretation, reviewed the drafted manuscript. SJ design of laboratory testing, chlamydia testing, interpretation of results. NES designed the study, supervised laboratory testing, reviewed the drafted manuscript. BSP conception, design, coordinated the study, interpreted data and reviewed the drafted manuscript. All authors read and approved the manuscript.

\section{Acknowledgements}

The authors thank the participating women for their time, the team of nurses and laboratory staff at Majengo and Pasua clinics for their hard work, and Robert K Stallman for review of the manuscript. This study was supported by a grant from the Letten Foundation.

\section{References}

I. World Health Organization: Global prevalence and incidence of selected curable sexually transmitted infections: overview and estimates Geneva: WHO; 2001

2. Mullick S, Watson-Jones D, Beksinska M, Mabey D: Sexually transmitted infections in pregnancy: prevalence, impact on pregnancy outcomes, and approach to treatment in developing countries. Sex Transm Infect 2005, 8 I :294-302.

3. Watson-Jones D, Changalucha J, Gumodoka B, Weiss H, Rusizoka M, Ndeki L, Whitehouse A, Balira R, Todd J, Ngeleja D, Ross D, Buve A, Hayes R, Mabey D: Syphilis in pregnancy in Tanzania. I. Impact of maternal syphilis on outcome of pregnancy. J Infect Dis 2002, I 86:940-947.

4. Gray RH, Wabwire-Mangen F, Kigozi G, Sewankambo N, Serwadda D, Moulton L, Quinn T, O'Brien K, Meehan M, Abramowsky C, Robb M, Wawer M: Randomised trial of presumptive sexually transmitted disease therapy during pregnancy in Rakai, Uganda. Am J Obstet Gynecol 2001, I 85: I 209-1217.

5. Mbizvo EM, Msuya SE, Stray-Pedersen B, Sundby J, Chirenje ZM, Hussain $A$ : HIV seroprevalence and its associations with the other reproductive tract infections in asymptomatic women in Harare, Zimbabwe. Int I STD AIDS 200I, I 2(8):524-53I.

6. Swai RO, Somi GR, Matee MI, Kilewo J, Lyamuya EF, Kwesigabo G, Tuli T, Kabalimu TK, Ng'anga L, Isingo R, Ndayongeje J: Surveillance of HIV and syphilis infections among antenatal clinic attendees in Tanzania 2003/2004. BMC Public Health 2006, 6:91.

7. Fleming D, Wasserheit J: From epidemiological synergy to public health policy and practice: the contribution of other sexually transmitted diseases to sexual transmission of HIV infection. Sex Transm Infect 1999, 75:3-17.

8. Bollen LJ, Whiteshed SJ, Mock PA, Leelawiwat W, Asavapiriyanont S, Chalermchockchareonkit A, Vanprapar N, Chotpitayasunondh T, McNicholl JM, Tappero JW, Shaffer N, Chuachoowong R: Maternal Herpes simplex virus type 2 coinfection increases the risk of perinatal HIV transmission: possibility to further decrease transmission? AIDS 2008, 22: I 169-1 I76.

9. Nagot N, Ouedraogo A, Foulongne V, Konate I, Weiss HA, Vergne L, Defer MC, Djagbare D, Sanon A, Andonaba JB, Becquart P, Segondy M, Vallo R, Sawadogo A, Perre P Van de, Mayaud P: Reduction of HIV-RNA levels with therapy to suppress Herpes simplex virus. N Engl J Med 2007, 356:790-799.

10. Taha TE, Gray R: Genital tract infections and perinatal transmission of HIV. Ann N Y Acad Sci 2000, 91 8:84-98.

11. Pol B Van Der, Kwok C, Pierre-Louis B, Rinaldi A, Salata RA, Chen PL, Wijgert J van de, Mmiro F, Mugerwa R, Chipato T, Morrison CS: Trichomonas vaginalis infection and human immunodeficiency virus acquisition in African women. J Infect Dis 2008, I 97(4):548-554.

12. Wijgert JH van de, Morrison CS, Cornelisse PG, Munjoma M, Moncada J, Awio P, Wang J, Pol B Van der, Chipato T, Salata RA, Padian NS: Bacterial vaginosis and vaginal yeast, but not vaginal cleansing, increase HIV-I acquisition in African women. J Acquir Immune Defic Syndr 2008, 48(2):203-210.

13. Mmbaga EJ, Hussain A, Leyna G, Klouman E, Masenga E, Sam N, Mnyika K, Klepp K: Incidence of HIV-I infection and changes in the prevalence of reproductive tract infection and sexual risk behaviours: a population based longitudinal study in rural Tanzania. AJAR 2006, 5(3):28I-287.

14. Kapiga SH, Sam NE, Mlay J, Aboud S, Ballard RC, Shao JF, Larsen U: The epidemiology of HIV-I infection in northern Tanzania: results from a community-based study. AIDS Care 2006, I 8(4):379-87.

15. Jordan-Harder B, Maboko L, Mmbando D, Riedner G, Nagale E, Harder J, Kuchen V, Kilian A, Korte R, Sonnenburg F: Thirteen years HIV-I sentinel surveillance and indicators for behavioural change suggest impact of programme activities in south-west Tanzania. AIDS 2004, I 8:287-294.

16. Riedner G, Hoffmann O, Rusizoka M, Mmbando D, Maboko L, Grosskurth H, Todd J, Hayes R, Hoelscher M: Decline in sexually transmitted infection prevalence and HIV incidence in female barworkers attending prevention and care services in Mbeya region, Tanzania. AIDS 2006, 20:609-6I5.

17. Ao TT, Sam NE, Masenga EJ, Seage GR 3rd, Kapiga SH: Human immunodeficiency virus type I among bar and hotel workers in northern Tanzania: the role of alcohol, sexual behavior, and herpes simplex virus type 2. Sex Transm Dis 2006, 33(3): 163-9.

18. Msuya SE, Mbizvo EM, Stray-Pedersen B, Sundby J, Sam NE, Hussain $A$ : Reproductive tract infections among women attending primary health care facilities in Moshi, Tanzania. East Afr Med J 2002, 79: |6-21.

19. National Bureau of Statistics (NBS) ORC Macro: Tanzania Demographic and Health Survey 2004-2005 Dar es Salaam, Tanzania: National Bureau of Statistics and ORC Macro; 2005.

20. Msuya SE, Mbizvo EM, Uriyo J, Stray-Pedersen B, Sam NE, Hussain A: Predictors of failure to return for HIV test results among pregnant women in Moshi, Tanzania. J Acquir Immune Defic Syndr 2006, 43(I):85-90.

21. Amsel R, Totten MS, Spiegel CA, Chen KC, Eschenbach D, Holmes KK: Non specific vaginitis: diagnostic criteria and microbiological and epidemiological associations. Am J Med 1983, 74(I): I4-22.

22. Lujan J, de Onate WA, Delva W, Claeys P, Sambola F, Temmerman $M$, Fernando J, Folgosa E: Prevalence of sexually transmitted infections in women attending antenatal care in Tete province, Mozambique. SAMI 2008, 98(I):49-5I.

23. Nagot N, Meda N, Ouangre A, Ouedraogo A, Yaro S, Sombie I, Defer MC, Barennes H, Perre P Van de: Review of STI and HIV epidemiological data from 1990 to $200 \mathrm{I}$ in urban Burkina Faso: implications for STI and HIV control. Sex Transm Infect 2004, 80:124-129.

24. Mbu E, Kongnyuy E, Mbopi-Keou FX, Tonye R, Nana P, Leke R: Gynaecological morbidity among HIV positive pregnant women in Cameroon. Reproductive Health 2008, 5:3.

25. Lumbiganon P, Piaggio G, Villar J, Pinol A, Bakketeig L, Bergsjø P, AlMazrou Y, Ba'aqeel H, Belizan J, Farnot U, Carroli G, Berende H: The epidemiology of syphilis in pregnancy. Int J STD AIDS 2002, I 3:486-494.

26. McClelland RS, Lavreys L, Katingima C, Overbaugh J, Chohan V, Mandaliya K, Ndinya-Achola J, Beaten : Contribution of HIV-I infection to acquisition of sexually transmitted disease: a 10 -year prospective study. J Infect Dis 2005, 191:333-338.

27. Kamenga M, De Cook K, St Louis M, Toure C, Zakaria S, N'gbichi JM, Ghys PD, Holmes KK, Eschenbach DA, Gayle HD: The impact of human immunodeficiency virus infection on pelvic inflammatory disease: case-control study in Abidjan, Ivory Coast. Am J Obstet Gynecol 1995, I 72:919-925.

28. Wang CC, McClleland RS, Reilly M, Overbaugh J, Emery SR, Mandaliya K, Chohan B, Ndinya-Achola J, Bwayo J, Kreiss JK: The effect of treatment of vaginal infections on shedding of human immunodeficiency virus type I. J Infect Dis 200I, I 83:1017-1022.

29. McClleland RS, Wang CC, Mandaliya K, Overbaugh J, Reiner MT, Panteleeff DD, Lavreys L, Ndinya-Achola J, Bwayo J], Kreiss JK: Treatment of cervicitis is associated with decreased cervical shedding of HIV-I. AIDS 200I, I 5(I): I05-II0.

30. Drake AL, John-Stewart GC, Wald A, Mbori-Ngacha DA, Bosire R, Wamalwa DC, Lohman-Payne BL, Ashley-Morrow R, Corey L, Farqu- 
har C: Herpes simplex virus type 2 risk and risk of intrapartum human immunodeficiency virus transmission. Obstet Gynecol 2007, 109:403-409.

31. Chi B, Mudenda V, Levy J, Sinkala M, Goldenberg RL, Stringer JS: Acute and chronic chorioamnionitis and the risk of perinatal human immunodeficiency virus-I transmission. Am J Obstet Gynecol 2006, 194(I): 174-I8I.

32. Wendel KA, Erbelding EJ, Gaydos CA, Rompalo AM: Trichomonas vaginalis polymerase chain reaction compared to standard diagnostic and therapeutic tools for detection and treatment of vaginal trichomoniasis. Clin Infect Dis 2002, 35:576-80.

33. Knox J, Tabrizi SN, Miller P, Petoumenos K, Law M, Chen S, Garland SM: Evaluation of self-collected samples in contrast to practioner-collected samples for detection of Chlamydia trachomatis, Neisseria gonorrhoeae, and Trichomonas vaginalis by polymerase chain reaction among women living in remote areas. Sex Transm Dis 2002, 29(I I):647-54.

Publish with Bio Med Central and every scientist can read your work free of charge

"BioMed Central will be the most significant development for disseminating the results of biomedical research in our lifetime. "

Sir Paul Nurse, Cancer Research UK

Your research papers will be:

- available free of charge to the entire biomedical community

- peer reviewed and published immediately upon acceptance

- cited in PubMed and archived on PubMed Central

- yours - you keep the copyright 